\title{
PENGARUH BUDAYA ORGANISASI DAN DISIPLIN KERJA TERHADAP KINERJA PEGAWAI DI BADAN KESATUAN BANGSA DAN POLITIK
}

\author{
Komang Erna Andriani, I Gusti Ngurah Agung Dwi Ananda Reraspatika \\ Suardi, I Dewa Ayu Heriyanti, Luh Putriasih \\ Jurusan Akuntansi, Universitas Pendidikan Ganesha, Singaraja, Bali, Indonesia
}

\begin{abstract}
Abstrak
Penelitian ini bertujuan untuk megetahui bagaimana pengaruh budaya organisasi terhadap kinerja pegawai di Badan Kesatuan Bangsa dan Politik, bagaimana pengaruh disiplin kerja terhadap kinerja pegawai di Badan Kesatuan Bangsa dan Politik. Jenis data dalam penelitian ini yaitu data Kualitatif yaitu data yang dinyatakan dalam bentuk kata-kata atau bukan dalam bentuk angka. Sumber data yang digunakan dalam penelitian ini yaitu data primer (primary data). Metode analisis data yang digunakan dalam pembahasaan penelitian ini adalah metod analisis data deskriptif. Pengaruh budaya organisasi terhadap kinerja pegawai sangat tinggi karena budaya organisasi itu terhadap perilaku kepemimpinan. Selain itu, kedisiplinan pegawai dalam organisasi sangat penting dalam meningkatkan kinerja pegawai, karena pegawai yang disiplin akan membuat tingkat kinerja suatu organisasi menjadi bai. Namun, pada Badan Kesatuan Bangsa dan Politik mengenai penerapan disiplin pegawai itu belum terlaksana dengan baik dikarenakan pegawai banyak yang datang terlambat, ada pula yang mangkir kerja tanpa memberi keterangan ke kantor.
\end{abstract}

Kata kunci: Budaya, Disiplin, Kinerja

\begin{abstract}
This study aims to determine how the influence of organizational culture on employee performance in the National Unity and Politics Agency, how the influence of work discipline on employee performance in the National Unity and Politics Agency. The type of data in this study is qualitative data that is data expressed in the form of words or not in the form of numbers. The data source used in this study is primary data. Data analysis method used in the discussion of this research is descriptive data analysis method. The influence of organizational culture on employee performance is very high because the organizational culture of leadership behavior. In addition, employee discipline in an organization is very important in improving employee performance, because disciplined employees will make an organization's level of performance good. However, the National Unity and Politics Agency regarding the application of employee discipline has not been carried out properly because many employees arrive late, some are absent from work without giving information to the office.
\end{abstract}

Keywords : Culture, Discipline, Performance

\section{Pendahuluan}

Organisasi merupakan suatu sistem aktivitas kerja sama yang dilakukan oleh dua orang atau lebih untuk mencapai sebuah tujuan yang sama. Perkembangan organisasi diera globalisasi yang semakin pesat membuat persaingan dalam suatu organisasi pun semakin ketat. Sumber daya manusia memiliki peran penting dalam persaingan bisnis saat ini. Dikatakan bahwa perusahaan dengan sumber daya manusia yang baik akan dapat bersaing dengan perusahaan lainnya. Hal ini membuktikan bahwa kualitas sumber daya manusia juga menentukan kualitas dan masa depan perusahaan tersebut. Menurut Stephen P. Robbins Organisasi adalah entitas sosial yang terkoordinir secara sengaja dan memiliki batasan yang mampu dipahami serta bergerak berdasarkan acuan yang berjalan sepanjang waktu dalam rangka meraih tujuan bersama.

Suatu organisasi dirasa perlu memperhitungkan budaya organisasi yang kuat dan sejalan dengan beberapa batasan-batasan yang berlaku. Selama memiliki budaya organisasi yang kuat, berdampak baik dan dapat diterapkan dengan baik oleh anggota organisasi tersebut maka dapat memperlancar aktivitas organisasi serta efektifitas kinerja karyawan. Kinerja sendiri dapat diartikan, hasil kerja yang dicapai oleh seseorang pegawai 
atau sekelompok pegawai dalam organisasi, sesuai dengan tanggung jawab dan wewenang masing-masing pegawai untuk mencapai tujuan organisasi yang tidak melanggar hukum dan sesuai dengan moral maupun etika. Faktor yang mempengaruhi kinerja pegawai adalah kedisiplinan. Kedisiplinan pada hakikatnya adalah kemampuan untuk mengendalikan diri dalam bentuk tidak melakukan suatu tindakan yang tidak sesuai dan bertentangan dengan sesuatu yang telah ditetapkan. Semangat kerja yaitu keinginan diri untuk bekerja dengan sungguh-sungguh untuk mencapai hasil yang diharapkan. Semangat kerja bisa timbul dari dalam diri sendiri maupun dari lingkungan sekitar.

Organisasi pemerintah seperti dinas atau badan pemerintah juga menggunakan budaya organisasi dan kedisiplinan dalam mengukur tingkat kinerja para pegawainya. Dengan hal itu peneliti meneliti apakah budaya organisasi itu sangat berpengaruh dalam tingkat kinerja pegawai atau tidak.

Berdasarkan latar belakang yang sudah diuraikan diatas, maka rumusan masalah/ topik permasalahan dalam penelitian ini adalah bagaimana pengaruh budaya organisasi terhadap kinerja pegawai di Badan Kesatuan Bangsa dan Politik, bagaimana pengaruh disiplin kerja terhadap kinerja pegawai di Badan Kesatuan Bangsa dan Politik.

\section{Metode}

\section{Jenis Penelitian}

Jenis penelitian adalah penelitian asosiatif atau hubungan. Menurut Sugiyono (2010: 380) penelitian asosiatif adalah penelitian yang bertujuan untuk mengetahui hubungan antara dua variabel atau lebih.

\section{Tempat dan Waktu Penelitian}

Penelitian ini dilakukan pada Badan Kesatuan Bangsa dan Politik dan waktu penelitian dilaksanakan pada bulan Desember 2018.

\section{Jenis Data}

Jenis data dalam penelitian ini yaitu data Kualitatif yaitu data yang dinyatakan dalam bentuk kata-kata atau bukan dalam bentuk angka. Misalnya : kuesioner pertanyaan tentang susunan kerja. Adapun jenis data kualitatif yang digunakan dalam penelitian ini yaitu tentang kedisiplinan dan kualitas kinerja dalam bekerja.

\section{Sumber Data}

Sumber data yang digunakan dalam penelitian ini yaitu data primer (primary data). Data primer adalah data yang dikumpulkan sendiri oleh perorangan atau suatu organisasi secara langsung dari objek yang diteliti dan untuk kepentingan studi yang bersangkutan yang berupa interview, observasi.

\section{Teknik Pengumpulan Data}

Untuk mencapai tujuan dalam penelitian ini maka metode analisis yang digunakan dalam penelitian ini adalah analisis regresi linier berganda yang adalah suatu metode statistik umum yang digunakan untuk meneliti hubungan antara antara sebuah variabel dengan beberapa variabel dependen. Dengan pemrosesan data menggunakan program komputer SPSS versi 20.

\section{Teknis Analisis Data}

Metode analisis data yang digunakan dalam pembahasaan penelitian ini adalah metod analisis data deskriptif. Menurut sugiyono (2009:207) "metode deskriptif adalah metode yang digunakan untuk menganalisis atau menggambarkan data yang telah terkumpul sebagaimana adanya tanpa bermaksud membuat kesimpulan yang berlaku untuk umum atau generalisasi". 


\section{Hasil dan Pembahasan \\ Pengaruh Budaya Kerja Terhadap Kinerja Pegawai Di Badan Kesatuan Bangsa Dan Politik}

Pengaruh budaya organisasi terhadap kinerja pegawai itu sangat tinggi, karena dalam budaya organisasi itu terdapat perilaku kepemimpinan, jujur, disiplin, bekerja sama satu sama lain dan lainnya. Seperti yang dikemukakan oleh Mangkunegara(2005:113) yang dikutip dari Edgar H Scheinmendefinisikan bahwa: Budaya Kerja adalahseperangkat asumsi atau system keyakinan,nilai-nilai dan norma yang dikembangkandalam organisasi yang dijadikan pedomantingkah laku bagi anggota-anggotanya untukmengatasi masalah adaptasi eksternal danintegrasi internal.

Dengan hal itu budaya organisasi sangat berperan penting terhadap kinerja pegawai disuatu organisasi. Seperti Badan Kesatuan Bangsa dan Politik yang peneliti teliti. Salah satu pegawai yang peneliti wawancarai mengungkapkan bahwa kinerja pegawai di lingkungan kantor tersebut baik, atasan atau pimpinan badan tersebut dalam memimpin pegawainya sangat baik, karena atasannya tersebut memberikan budaya organisasi seperti inovasi dan kedisiplinan. Dengan inovasi atau dorongan yang diberikan oleh pimpinan membuat pegawai menjadi semangat dalam mengerjakan pekerjaanya. Tidak hanya memberikan inovasi dalam kata-kata saja, pimpinan badan tersebut juga ikut serta membantu pegawainya dalam melakukan pekerjaannya. Selain itu pimpinan atau ketua badan juga sering melakukan komunikasi dengan pegawainya sehingga membuat ketua dan pegawai menjadi saling mengenal satu sama lain.

Dengan kesadaran dankesediaan seseorang untuk mentaati semuaperaturan, diharapkan pegawai yangbersangkutan akan meningkat kinerjanya,dengan demikian Budaya Kerja harusditegakkan dalam suatu organisasi. Jadi budayakerja adalah kunci keberhasilan suatuorganisasi dalam mencapai tujuan sehinggadapat dikatakan bahwa Budaya Kerjamempengaruhi kinerja pegawai.

\section{Pengaruh Disiplin Kerja Terhadap Kinerja Pegawai di Badan Kesatuan Bangsa Dan Politik}

Kedisiplinan pegawai dalam organisasi sangat penting dalam meningkatkan kinerja pegawai, karena pegawai yang disiplin akan membuat tingkat kinerja suatu organisasi menjadi baik. Mengetahui kinerja pegawaiberarti berusaha untuk mempelajari sertamemahami kinerja yang dimiliki olehpegawai dalam sebuah organisasi. Dengankata lain, disiplin kerja pegawai sangatmemiliki peran penting demi meningkatnya kinerja pegawai dalam suatuorganisasi. Informasi mengenai kinerja.

Pada setiap organisasi itu pastiharus menerapkan kedisiplinan demimeningkatkan kinerja pegawai, tetapi padaBadan Kesatuan Bangsa dan Politikmengenaipenerapan disiplin pegawai itu belum $100 \%$ dilaksanakan karena masih banyakpegawai yang kurang disiplin sepertidatang ke kantor yang tidak tepat waktuyang disebabkan oleh banyak kendalayang pegawai itu sendiri yang tahu apapenyebab mereka tidak bisa mendisiplinkan diri. Biasanya ada satu atau dua orang pegawaiyang tidak hadir tak memberikan kabarataupun disaat mereka hadir selalu datangterlambat maupun pulang belum waktunyasehingga untuk penerapan disiplin kerjabelum semua pegawai bisa melakukannyadengan baik.

Disiplin kerja pegawai pada Badan Kesatuan Bangsa dan Politikbelum berjalan sesuai aturan yang ada, masih banyak pegawai yang tidak menjalankan disiplin tersebut sehingga sangat berpengaruh terhadap kinerja pegawai khususnya pada pelayanan kepada masyarakat

\section{Simpulandan Saran Simpulan}

Pengaruh budaya organisasi terhadap kinerja pegawai sangat tinggi karena budaya organisasi itu terhadap perilaku kepemimpinan. Selain itu, kedisiplinan pegawai dalam organisasi sangat penting dalam meningkatkan kinerja pegawai, karena pegawai yang disiplin akan membuat tingkat kinerja suatu organisasi menjadi bai. Namun, pada Badan Kesatuan Bangsa dan Politik mengenai penerapan disiplin pegawai itu belum terlaksana 
dengan baik dikarenakan pegawai banyak yang datang terlambat, ada pula yang mangkir kerja tanpa memberi keterangan ke kantor. Maka, dari itu Badan Kesatuan Bangsa dan Politik dapat mencari solusi agar disiplin kerja dapat terlaksana dan pegawai dapat mengikuti peraturan yang ada.

\section{Saran}

Berdasarkan kesimpulan penelitian, maka peneliti dapat memberikan saran, yaitu untuk mengukur kinerja pegawai di Badan Kesatuan Bangsa dan Politik tersebut harus meningkatkan budaya organisasi yang diterapkan oleh pimpinan dan membuat peraturan untuk meningkatkan kedisiplinan pegawai tersebut.

\section{DAFTAR PUSTAKA}

Admin. 2018. Ciri-Ciri Budaya Organisasi yang Sehat. https://actconsulting.co/budayaorganisasi-organization-budaya-konsultan-budaya-corporate-culture-consultant/. Diakses : 28 Desember 2018

Andari, Sumilah. 2017. Variabel Penelitian - Teori Disiplin Kerja Dan Pengaruhnya Terhadap Kinerja Karyawan. https://artikelkuliahkita.blogspot.com/2017/04/variabel-penelitian-teori-disiplin.html. Diakses : 28 Desember 2018

Wikipedia. Budaya Organisasi. https://id.wikipedia.org/wiki/Budaya organisasi. Diakse : 28 Desember 2018

Yusuf. 2018. Pengertian Organisasi Secara Umum dan Menurut Para Ahli. https://jurnalmanajemen.com/pengertian-organisasi/. Diakses : 28 Desember 2018 